hence, puzzle same antiquarians, who may naturally assume that these races, speaking the same language, mean the same thing by the same word. They all are due to the jealousy usually felt by the introduction of new machinery in any industry. The set-line fishermen, who complain of the beam trawls in this country, form the very class which the hand-line fishermen complain of in America under the name of trawlers; and the Governments of both countries may safely disregard both complaints, since one of them is the most effective answer to the other.

We have reserved for the close of this article all reference to what the Commissioners would consider the most important portion of their Report. The Americans are the greatest fish-breeders in the world, and fish-breeding is conducted in the United States at a cost and to an extent of which in this country we can have little idea. According to the Report, the Commissioners distributed in 1878 no less than $15,700,000$ shad and 4,460,000 Californian salmon, besides other fish. Such prodigious efforts will excite surprise among persons who are acquainted with the difficulties of obtaining even a few thousand ripe salmon eggs, and we naturaliy turn for information as to the results which have ensued from such unprecedented efforts. Here however we find, as it seems to us, the least satisfactory portion of the Report. The Commissioners claim indeed that no less than 500 salmon were taken in the mouth of the Connecticut River in 1878, a river which they imply had had few or no salmon in it for many years. It is possible therefore that the Commissioners' efforts may have been successful in restocking that river with salmon; though we own that we should feel more certain of this if the fish had been taken in the river itself, and not in the mouth of it. But when they go on to infer that they may increase the yield of shad, and even of herring and of cod, we read with admiration of their energy, but without being convinced by their reasoning. In this country, at any rate, the best observers are satisfied that cod, herring, and other fish are annually bred in numbers compared with which the fifteen millions of fry of the United States Commission would represent an insignificant fraction, and that the destruction which is going on among them by natural causes is so vast that even the capture of white bait by the ton-load makes no appreciable addition to it. The arguments which Malthus, at the commencement of the century, used to illustrate the principles of population are thought in this country to be strictly applicable to fish. Sea-fish, like all other animals, are undoubtedly increasing in greater proportion than their food; and it is obvious therefore that unless man can increase their food it is only lost labour to increase their number.

We have thus reviewed, at some length, a few of the leading facts in this long and interesting Report. With many of the conclusions in it we are unable to agree; but we cannot part from it without expressing a feeling of almost envy at the elaborate pains which the Government of the United States is taking to understand the best methods of developing the great industries of their seas. In this country we do not even take steps to obtain the best statistical information on the subject. Might we not in such a matter with advantage follow the example of our Transatlantic kinsmen?

\section{THE PARIS OBSERVATORY 1}

$\mathrm{A}^{\mathrm{B}}$ BOUT two years ago Rear-Admiral Mouchez, director of the Paris Observatory, resolved to bring together for exhibition the instruments scattered in various parts, and by joining to that collection the portraits of great astronomers and methodically grouping all the documents relating to the history of astronomy which could be procured by bequest or otherwise, to lay the basis of a

${ }^{\mathbf{x}}$ From an article by $\mathbf{M}$. Gaston Tissandier in La Nature, and $\mathbf{M}$. Mouchez's official Report of 1880 . special museum of very great interest. This proposal, having received the approval of the Minister of Public Instruction, is now being realised. One of the large rooms on the first floor of the Observatory has already been fitted up and occupied, and through the kindness of Admiral Mouchez, who himself did us the honour of giving full details of his new collection, we are able to publish the description.

The first hall of the Astronomical Museum is very artistically decorated. It is circular in form, and well lighted by several windows. The ceiling will probably be adorned by a painting representing the transit of Venus over the Sun. There are nine paintings in the room, representing Louis XIV., founder of the Observatory, and directors and eminent astronomers who have

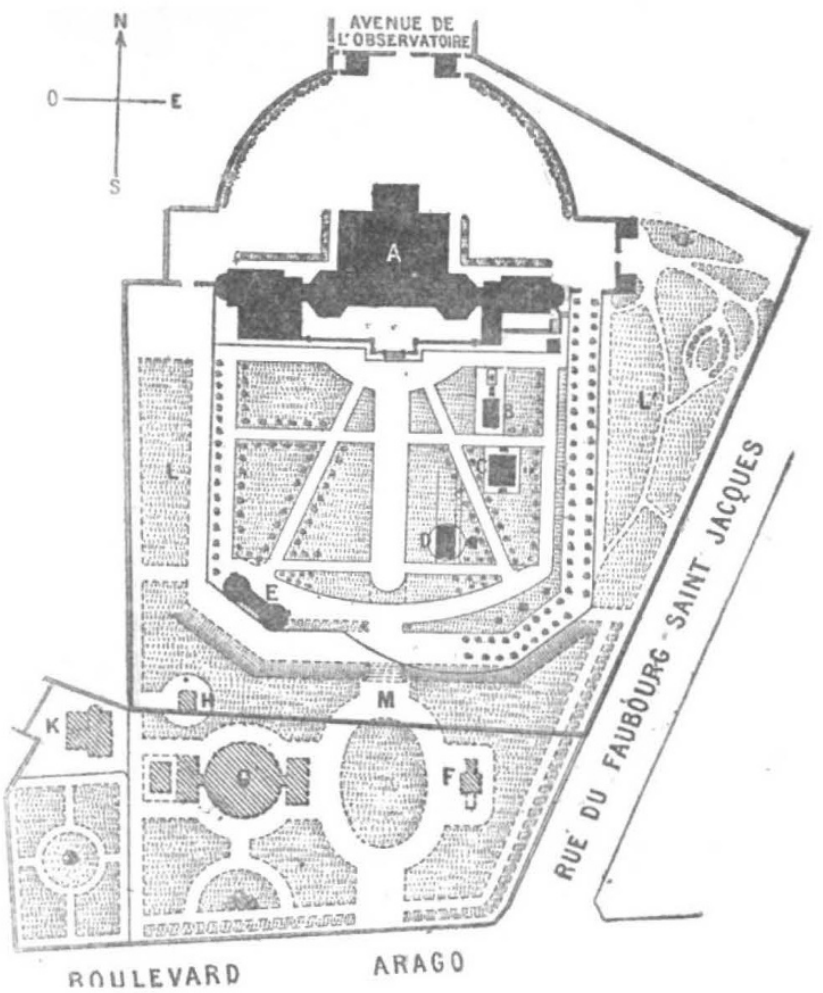

Fig. x.-Plan of the Observatory, with the proposed extension on the south side to the Boulevard Arago Present state: A, the Observatory ; B, the "siderostat" $\mathrm{C}$, the meridian circle; D, the great telescope; equatorials: $M$, ditch to be filled up; $L \mathrm{~L}$, ditches. Ground to be annexed ; the Bischoffsheim equatorial: $G$, the great refractor of $0.74 \mathrm{~m}$, aperture; $\mathrm{H}$, Fortin's circle; $\mathrm{k}$, the astronomers' dwelling-house.

succeeded each other to the present day : Cassini, Lalande, Delambre, Laplace, Bouvard, Arago, Delaunay, and Leverrier; the latter painted after cleath by Giacomotti, is the gift of M. Bischoffsheim. In the embrasures of the windows are displayed astronomical paintings representing groups of nebulæ, Saturn's rings, lunar volcanoes, clusters of stars, the remarkable drawings of Jupiter and Mars executed by MM. Henry, \&c.

On the oak mantelpiece stands a magnificent LouisQuatorze clock made by Coypel and recently restored by M. Passerat, a specimen of art so unique that virtuosos would certainly attach a great value to it. Round the room are observed several globes mounted on marble and oak pillars, two being especially worthy of attention : the celestial sphere of Gerard Mercator (155I), and the terrestrial sphere of the same geographer (154I). On the latter globe may be seen figured a certain number of the great lakes of Central Africa already known and their 
positions well indicated in the middle of the sixteenth century. These spheres, which constitute documents of great importance historically, were recently discovered at the Brussels library through a folio pamphlet bought in I 868 , and have been reproduced with great accuracy, by M. Malou.

The objects exhibited are carefully classified in glass cases, so that they can be examined by the visitor without being touched. In the first case, which is set apart for optical instruments, is observed Fresnel's great lens ; also some of the object-glasses made use of by Cassini, and other valuable objects presented to the Observatory by Mme. Laugier, such as the optical apparatus made use of by Arago; the photometer, prismatic mirrors, and the polarimeter, by means of which the great astronomer enriched science with so many beautiful discoveries.

The second case contains objects relating to the history of the "metric system," comprising a standard metre and several curious specimens of foreign measures. The other glass cases, arranged in a circle round the room, contain various astronomical instruments, among which we may mention the apparatus made use of by M. Cornu to measure the velocity of rays of light, a large theodolite of Rigaud, another of Bruner, one of the first sextants ever constructed; also several instruments of more modern date, the first portable meridian circle of $\mathrm{M}$. Mouchez, Gambey's theodolite, \&c.

The case in the centre of the room is especially

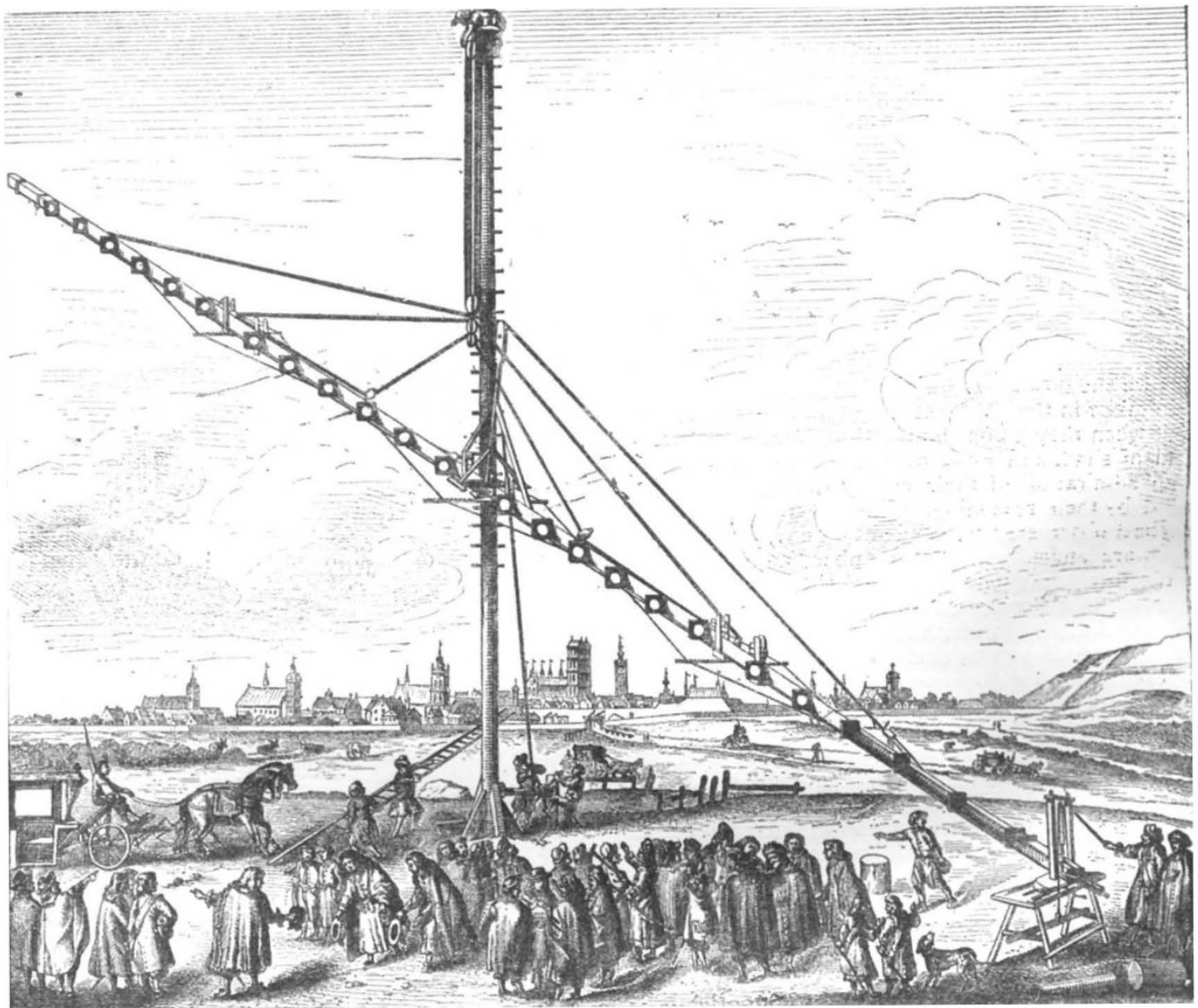

FIG. 2.-Aërial telescope of the seventeenth century, after Hevelius, from an engraving in the new Astronomical Museum of the Observatory of Paris.

noticeable: it contains a curious collection of German instruments of the sixteenth century, in perfect preservation. The attention is at once attracted by several instruments of gilt brass, most artistically carved, which were made at Nüremberg in the sixteenth century. Amongst them we observed a curious mechanical arrangement for casting dice, which was probably used for some demonstration of the doctrine of probability and chances; a valuable sun-dial of carved brass, dated 1578, full of groups of allegorical personages; a species of altazimuth; a handsome repeating-circle, highly ornamented, and bearing the two-headed eagle of Germany ; some astrolabes, quadrants, mariner's-compasses, a small ivory sun-dial of the sixteenth century, presented by M. Eichens. The history of all these instruments except the last is unknown; but it is supposed that they were either presented to Louis XIV. or are what is left from the spoil of the First Empire having escaped the notice of the Allies in 1815 .

On the lower part of this case are shown photographs of old engravings representing the astronomical instruments of former ages. One of those curious pictures is reproduced above (Fig. 2), showing the astronomical telescope with a simple object-glass of long focus which was constructed in the seventeenth century, and of which an engraving was published by Hevelius. It may serve to convey an idea of the singular and gigantic instruments which astronomers of bygone times made use of. 
In a room on the floor above there is a special exhibition of a large number of photographs, which is being constantly increased by new additions. They consist of photographs of all the ancient instruments copied from engravings of the period; and all the foreign instruments in present use, taken from nature. There are also drawings representing the principal observatories in the world.

Such is the commencement of the astronomical museum of the Paris Observatory. It will be completed by organising a second circular room resembling that which we have just rapidly passed under review. This new room will be adorned with portraits of the most illustrious of foreign astronomers :--Newton, Galileo, Tycho-Brahe, Kepler, Copernicus, Herschel, Bradley, and others. It will also contain a special exhibition of large astronomical instruments; notably a quadrant of Lalande's, a sextant of Lacaille's, a quadrant of Langlois' which was used by the North Pole Committee, and a meridian telescope of Delambre.

It would be useful to bring together in the Paris Observatory those instruments which are scattered here and there in various other national institutions, so as to complete a collection already so rich in valuable objects. The directors will also gratefully accept of any bequests that may be addressed to them from private individuals, as was done by Mme. Laugier with reference to the instruments of Arago and Delambre which she had in her possession.

After our survey of the new Astronomical Museum, it now remains to say a few words regarding the extension of the observatory, which is about to be made by annexing the ground on the Boulevard Arago (Fig. I). This waste land contains a superficies of at least 9000 metres, and when the ditch which at present divides it from the $\mathrm{Ob}$ servatory garden is filled up, it will be united to the rest of the institution without any separation. On these grounds will be erected the great $75 \mathrm{~m}$. telescope, the arrangements for which are already well advanced; also the equatorial presented by M. Bischoffsheim, the circle of Fortin, which long rendered excellent service, and was dismounted in 1862 to make room for the the great meridian-circle, and several instruments for the special use of the pupils.

The plan which we give above (Fig. I), from official documents, shows what the Paris Observatory will be as a whole when the projected improvements are completed.

We regret that the works are being so slowly carried on, notwithstanding the praiseworthy energy evinced by the directors of the Observatory. A ditch to be filled in, a garden to be laid out, a few buildings to be erected, all amount to but very little. But before the masons cut a stone or the gardeners trace an alley there is a path to be traversed which is not exactly the shortest or quickest, viz. that of administrative and official routine.

\section{ACHILLE DELESSE}

WE regret to have to record the death of this eminent geologist, which took place, after a long illness, on March 24. Delesse was born at Metz, and was educated at the lyceum of that town, afterwards proceeding, at the age of twenty, to the École Polytechnique at Paris. He was a diligent and successful student, and in 1839 took his degree as a mining engineer. $\mathrm{He}$ then travelled for some time through his own country, in Germany, Poland, and the British Islands, and in 1845 was appointed Professor of Geology and Mineralogy at Besançon, where he also practised as a mining engineer. It was during his residence here that he wrote his "Notice sur les Characteres de l'Arkose dans les Vosges," and his "Memoire sur la Constitution minéralogique et chimique des Roches de Vosges," both of which works appeared in 1847 . After a stay of five years at Besançon
Delesse returned to Paris, where he was employed as a mining engineer, and was especially engaged in superintending the quarrying operations about the city for nearly eighteen years. In 1855 he prepared the report on building materials in connection with the Exposition Universelle of that year in Paris. In 1864 he was nominated Professor of Agriculture, Drainage, and Irrigation in the École des Mines. Delesse's earliest researches were directed to pure mineralogy, and he paid great attention to the subjects of pseudomorphs and the association of minerals, and this led him to study the question of the metamorphism of rocks. The outcome of this perioc" cf study was his well-known work, "Recherches sur l'Origine des Roches," published in 1865 , in which he argued ably and forcibly in favour of the view that crystalline rocks owe many of their characters to the action of superheated water, and are not produced by simple dry fusion. This important work of Delesse has exercised a marked and very beneficial influence on the progress of petrographical science, and its originality and value were at once recognised by the most advanced thinkers of the time. Already in 1858 Delesse had published two of his valuable maps, namely, the "Carte géologique soutteraine de la Ville de Paris" and the "Carte hydrologique de la Ville de Paris," and his subsequent studies came to be especially directed into the channels of inquiry which were associated with the professorship that he had created and so ably filled. In 1868 appeared his work on the Rainfall of France, and other memoirs treating of the agricultural bearings of geology were produced about the same period.

The war of 1870 caused an interruption in the scientific labours of Delesse, and we find him at this period superintending the construction of cartridges in the departments. But in 1878 he was appointed an InspectorGeneral of Mines, and the south-east of France was assigned to him as his district. During the last twenty years Delesse has issued, in conjunction with MM. Langel and de Lapparent, a series of annual volumes entitled "Revue de Géologie," a work of such value that we regret to hear that it is to be discontinued in the future. Delesse received many honours in recognition of his valuable labours. He was an officer of the Legion of Honour, and filled the post of President of the Geological Society of France. As long ago as 1859 he was elected a Foreign Member of our own Geological Society. He was also for two years President of the French Geological Society, and he occupied the chair during the International Congress of that Society in 1875 . In 1879 Delesse was elected a Member of the Academy of Sciences. In Delesse France has lost one of her most distinguished and widely-known scientific men.

\section{PROFESSOR HELMHOLTZ'S FARADAY LECTURE}

$\mathrm{N}$ Tuesday evening Prof. Helmholtz gave the Faraday Lecture of the Chemical Society at the Royal Institution. We have so recently (NATURE, vol. xv. p. 389) given a full account of the life and work of the eminent German worker in various departments of science, that it is unnecessary to go over the ground again. A very fair estimate of his position was given in a leading article in the Times of Saturday last; and we are glad to notice that the leading journal now is glad to draw attention to men of science whose work is deserving of public notice. The University of Cambridge did itself the honour of conferring upon Prof. Helmholtz the degree of LL.D. on Thursday last, on which occasion the public orator, Mr. Sandys, made the following elegant and appropriate speech :--

"Dignissime domine, domine Procancellarie, et tota Academia :

"Singularum quidem scientiarum terminos protulisse, 